FOLIA SCANDINAVICA VOL. 24 POZNAŃ 2018 DOI: $10.2478 /$ fsp-2018-0002 sciendo

\section{PRESSto.}

\title{
OM POSTKOLONIALISME, MIGRASJONSPROSESSER OG HYBRIDE IDENTITETER. EN LESNING AV EVA SCHEERS VI BYGGER I SAND (1948)
}

\author{
MADELEN MARIE BROVOLD \\ University of Oslo
}

ABSTRACT.This article examines what one might call migration literary features in the Jewish Norwegian author Eva Scheer's novel Vi bygger $i$ sand (1948). I will investigate themes and sections that in different ways emphasize the migration experience of the characters within the novel. The focal point of the analysis is the migration experience in itself, what it means to be forced to move from one country to another and having to learn how to live in a different country and community, perceived identity and identity issues, prejudices, anti-Semitism and the fear of persecution. Because of this chosen focal point, I will use postcolonial theory in my reading of the novel, emphasizing Homi K. Bhabha's concepts of mimicry and hybridity. What does it mean to belong to a nation? Is it possible to become Norwegian while keeping parts of your homeland's identity? With the altered migration pattern of recent decades, such issues make the novel relevant even today.

\section{INNLEDNING}

Eva Scheer (1915-1999) var i mange år aktiv i norsk kulturliv gjennom sitt varierte litteraturengasjement, og jobbet blant annet som journalist, litteraturanmelder, forfatter, foredragsholder og radiokåsør i NRK. ${ }^{1}$ I 1948 ble hennes debutroman Vi bygger $i$ sand utgitt. Senere fulgte eventyrsamlingene Posene på gjerdestolpen (1977) og Papirbroen (1979), trilogien Tre er fedrene, fire mødrene (1981), En smak av vintreets frukt (1982) og Hundene gjør ved vanningsstedet (1983), barneboken Teddybjørn på bølgelengde (1954) og to dokumentariske reportasjebøker med temaer fra

${ }^{1}$ Se blant annet Berthelsen, 1987:369. 
Israel: Vi møttes i Jerusalem (1951) og Israel - dobbeltløftets land (1967). ${ }^{2}$ Dessuten finner vi novellen "Kosakkene kommer" i antologien Jødiske fortellere (1983), redigert av Ragnar Kvam. Med unntak av barneboken, omhandler hele hennes forfatterskap minoritets- og delvis også migrasjonstematikk. Etter hennes død har en ny utgave av Vi bygger $i$ sand blitt utgitt (2016), i tillegg til en samling av fortellinger fra forfatterskapet under tittelen Jødiske fortellinger. Fra shtetl til Grünerløkka (2015). ${ }^{3}$

Scheer er den første norsk-jødiske forfatteren som skriver skjønnlitteratur om jødisk identitet, kultur og historie uten å skildre jødeforfølgelsene under andre verdenskrig. Drapet på jøder, inkludert mange av hennes egne familiemedlemmer, og det hun beskriver som Hitlers forsøk på å utrydde en hel kultur, omtales i forfatterskapet, men det er ikke primært dette hennes litteratur handler om. I stedet beskriver Scheer levde liv, fiktive og faktiske, og forsøker å gi leserne et innblikk i den tapte shtetlkulturen og dagliglivet der, og livet til jødiske migranter i Norge i første halvdel av 1900-tallet. Men også av andre årsaker står Vi bygger $i$ sand i en særstilling i norsk litteraturhistorie: Dette er den første norske romanen som beskriver jødisk migrasjon (til Norge). ${ }^{4}$ Golde Scheer var navnet på Evas bestemor, og en romanfigur med samme navn har en sentral plass i flere av hennes bøker. Forfatterskapet bunner i et ønske om å skrive ned og samle bestemorens fortellinger, for å dele dem med andre (Scheer, 1981:12; Bingen, 1987:14).

Sekundærlitteraturen om Eva Scheer og forfatterskapet hennes er svært begrenset. Så vidt meg bekjent er det tidligere ikke forsket på hennes bidrag til norsk kulturliv og litteraturhistorie. Tiden er derfor inne for å løfte henne frem. Ikke minst er forfatterskapet hennes interessant i lys av de siste tiårenes interesse for minoritets- og migrasjonslitteratur i europeisk offentlighet, hvorav Scheer må sies å være en tidlig bidragsyter i norsk kontekst. I den foreliggende artikkelen har jeg valgt å fokusere på debutromanen Vi bygger $i$ sand fra 1948, som bør anses som hennes hovedverk. Dette skyldes at denne boken er hennes mest allmennappellerende, samt at dette er boken om bestemoren, som var en svært viktig informasjons- og inspirasjonskilde. I denne artikkelen skal jeg

${ }^{2}$ Om Posene på gjerdestolpen (1977), se Borgen, 1977:4; Flottorp, 1977:2; Nationen, 18. mars 1977:12; Lange-Nielsen, 1977:7; Om Vi møttes i Jerusalem (1951), se Nordal, 1951:2 og Rana Blad, 14. november 1951:4. Om Papirbroen (1979), se Johansen, 1979:15. Om Tre er fedrene, fire mødrene (1981), se Flottorp, 1981:6; Johansen, 1981:5 og Tjønneland, 1981:13. Om En smak av vintreets frukt (1982), se Johansen, 1982:16. Om Hundene gjør ved vanningsstedet (1983), se Johansen, 1983:4. Se for eksempel Scheer, 1956:3-4 og Scheer, 1987:20 for å få en "smakebit" av hennes journalistiske virke.

${ }^{3}$ For å lese om mottakelsen av Jødiske fortellinger (2015), se Larsen, 2015; Pedersen, 2015:40-41 og Surén, 2015:30.

${ }^{4}$ For resepsjonen av Vi bygger $i$ sand, se Brekke, 1948:5; Dagbladet, 12. oktober 1948:5; Dagbladet, 2. november 1948:3; Sarpsborg Arbeiderblad, 16. november 1948:5; Me., 1948:2, Rana Blad, 22. november 1948:3; Arbeiderbladet, 3. november 1948:2. 
undersøke det vi kan kalle migrasjonslitterære trekk ved Vi bygger $i$ sand. Dette innebærer at jeg vil undersøke temaer og episoder som på ulike måter belyser migrasjonserfaringen til romanfigurene. Det dreier seg særlig om selve migrasjonserfaringen - det vil si det å være nødt til å flytte fra ett land til et annet, selve reisen og det å skulle lære seg å leve i et annet land - følelsen av identitet og identitetsproblematikk, fordommer, antisemittisme og den evige frykten for jødeforfølgelser. Disse perspektivene åpner opp for bruk av postkolonial teori i lesningen av romanen, med vekt på Homi K. Bhabhas begreper mimicry og hybriditet. Hva betyr immigrasjonen til Norge for romanens personer? Hva gjør migrasjonserfaringen med særlig andregenerasjonens identitetsforståelse? Oppnår andregenerasjonen en såkalt kulturelt hybrid identitet, eller er de fastlåst i mimicry-mekanismen Bhabha beskriver?

\section{TIDLIGERE FORSKNING}

Sekundærlitteraturen om Eva Scheer er som nevnt svært begrenset. I norsk litteraturhistorisk kontekst behandles hun i hovedsak i Norsk kvinnelitteraturhistorie (1990), og der kun med svært få ord. I forbigående nevnes forfatterskapet i sammenheng med bøker som vitner om "en bevissthet om etniske og kulturelle minoriteter og minoritetskonflikter", og det beskrives som bøker "om et jødisk samfunn i Litauen i forrige århundre" (Rønning, 1990:69). Scheer nevnes imidlertid ikke i sentrale norske litteraturhistorier som Per Thomas Andersens Norsk litteraturhistorie, eller Francis Bull, Fredrik Paasche, A. H. Winsnes og Philip Houms Norsk litteraturhistorie (Andersen, 2001:593; Bull et al., 1955:597). I Oskar Mendelsohns historiske standardverk

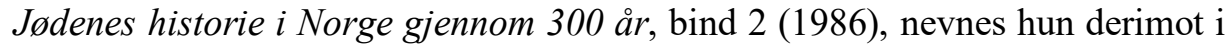
ulike sammenhenger. Her skrives det om hennes mangefasetterte virke gjennom årenes løp. Den grundigste gjennomgangen av forfatterskapet finner vi i doktorgradsavhandlingen "Vom Schtetl zum Polarkreis. Juden und Judentum in der norwegischen Literatur" av Gertraud Rothlauf (2009), hvor Rothlauf skriver noen sider om det. ${ }^{5}$

\section{VI BYGGER I SAND (1948)}

Vi bygger $i$ sand er en slektsroman som spenner over fire generasjoner og som med biografiske trekk omhandler Golde og hennes families liv i diaspora $i$ shtetlmiljøet i Samelan, Libau og Morowjow i det russiske tsarriket, i Argentina og i Kristiania. Romanen ble utgitt i begynnelsen av november 1948 på Tiden norsk forlag. Ifølge et intervju med Eva Scheer i Sarpsborg

\footnotetext{
${ }^{5}$ Om Scheers forfatterskap, se Rothlauf, 2009:200-204; om Vi bygger $i$ sand, se Rothlauf, 2009:323, 330, 356, 371.
} 
Arbeiderblad var utgivelsestidspunktet nøye valgt fra forlagets side: "Forlaget bestemte at boka kom ut samtidig som minnestøtten over de deporterte jøder reistes i Oslo 1. november" (Sarpsborg Arbeiderblad, 16. november 1948:5). Handlingen i Vi bygger $i$ sand bygger i stor grad på Golde Scheers historie eller Eva Scheers kunnskap om og tolkning av den. Dette fremgår av et notat om inntrykk fra hennes første tysklandsbesøk: "Etter at jeg kom hjem til Norge ville jeg skrive historien om bestemor, boken heter 'Vi bygger i sand" (dokument merket "Møtet 23/11.-87.", i JMO.D00387).

\subsection{BYGGER I SAND SOM MIGRASJONSROMAN}

I sin artikkel "Norsk migrasjonslitteratur" definerer litteraturforsker Jørgen Magnus Sejersted migrasjonslitteratur som

ein tematisk definisjon av litteratur (her skjønnlitteratur) som omhandlar og tematiserer den kulturelle problematikken som oppstår når eit individ eller ei gruppe frå eitt kulturelt område kjem i (varig) kontakt med ein annan, og i utgangspunktet framand, kultur (Sejersted, 2002:80).

Sejersted skiller migrasjonslitteraturbegrepet fra innvandrerlitteraturbegrepet. Innvandrerlitteraturbegrepet tar utgangspunkt $i$ at forfatteren selv har bakgrunn som immigrant, i motsetning til hva tilfellet er med migrasjonslitteratur. Han påpeker at kategoriene er overlappende, men at immigranter ikke bare skriver litteratur som tematiserer migrasjonserfaringer, mens også ikke-immigranter kan tematisere migrasjonserfaringer på tross av at de ikke selv har det (80). ${ }^{6}$ Eva Scheers Vi bygger $i$ sand er en innvandrerroman med migrasjonsperspektiv, $i$ og med at hun kan defineres som såkalt andregenerasjonsinnvandrer. Basert på Sejersteds definisjon kan den også defineres som migrantlitteratur. Både de mest sentrale motivene, som diasporamotivet og kulturmøtemotivet, og temaene, som antisemittisme og identitet, er knyttet til migrasjonsperspektivet.

For å forstå Scheers roman, kan begrepene diaspora og hybriditet være til hjelp. I sin tekst "Diaspora and Hybridity" (2010) skriver sosiologiprofessor Claire Alexander at diaspora og hybriditet er relaterte fenomener. Noen anser diaspora som en måte å tenke om forflytning og (re)produksjon av identiteter i nye kontekster på, mens hybriditet er det som skjer i møtet mellom kulturer. Denne distinksjonen opprettholdes imidlertid ikke alltid, og noen teoretikere

${ }^{6}$ I tråd med Sejersteds forståelse av migrasjonslitteraturbegrepet, foreslår den danske litteraturforskeren Søren Frank å endre den engelske betegnelsen fra "migrant literature" til "migration literature". Dette for å forflytte fokuset fra forfatterbiografien til fordel for en vektlegging av intratekstuelle, tematiske og formmessige trekk så vel som ekstratekstuelle trekk som sosiale prosesser (Frank, 2008:3). 
ser diasporakulturer som stedet for hybriditet, eller det Homi Bhabha kaller det tredje rommet. Her blir også diaspora en hybrid formasjon, mens hybriditet er et uunngåelig resultat av diasporamøter (Alexander, 2010:4). Forståelsen av identitet som en prosess, formet $\mathrm{i}$ interaksjon med det gamle og det nye hjemlandet og smidd i "migrasjonens turbulens", er stedet hvor begrepene diaspora og hybriditet krysser hverandre. Hybriditet kan forstås som det som skjer på diasporaens grenser; det vil si hvor diaspora møter og interagerer med vertsnasjonen, og hvor nye kulturelle former og identiteter oppstår (9).

Vi bygger $i$ sand handler om en jødisk familie som lever i en shtetl i tsarRussland fra omkring 1890. Jødene fikk kun bo isolert i shtetler, og livet der skilte seg ut fra omgivelsene og livet blant ikke-jødene (Scheer, 1979:10). I Encyclopaedia Judaica kan vi lese at shtetl er en jiddisch diminutiv for shtot, som betyr småby ("town") eller by ("city"), og betegner et relativt lite samfunn. Shtetlene var et særegent østeuropeisk sosiokulturelt fenomen, og har ingen klart definerte størrelseskriterier; innbyggertallene kunne variere fra langt lavere enn 1000 til over 20000 eller mer. Shtetlene vokste frem i det polsk-litauiske riket på 1500-tallet. Forholdene i særlig de russiske shtetlene ble stadig verre gjennom 1800-tallet på grunn av blant annet antijødiske forfølgelser og økonomiske restriksjoner, hvilket førte til at levekårene i shtetlene fremstod stadig mindre appellerende for de yngre generasjonene (Zborowski \& Freeze, 2007:524). Dette er også grunnen til at romanfiguren Golde og ektemannen emigrerer til Argentina på 1890-tallet. På den argentinske pampasen forsøker de å skape seg et nytt liv med sine barn, men de mister to av dem og etter hvert alt de har bygget seg opp, og bestemmer seg for å reise hjem igjen etter få år. Familien trives nokså godt hjemme i Russland igjen, og vokser, men de gamle problemene, det vil særlig si frykten for pogromer, fører til at familien flytter til Norge i $1905 .^{7}$ Her trives de godt, og går inn for å lære seg språket, arbeide, gå på skole og bygge seg et nytt liv. Handlingen sirkler rundt de ulike familiemedlemmene og hverdagens små og store bekymringer. Vi bygger $i$ sand er med andre ord en kollektivroman uten noen bestemt hovedperson, men der migrasjons- og identitetstematikk drøftes fra ståstedet til flere ulike aktører. De sentrale personene i boken er matriarken Golde og hennes mann Måte-Mende, og barna deres, oppgitt etter synkende

${ }^{7}$ Ifølge historiker Oskar Mendelsohn er det først i siste fjerdedel av det 19. århundret at den jødiske innvandringen til Norge nådde et slikt nivå at det kunne bli snakk om å danne noe jødisk samfunn i landet. Det er trolig mange årsaker til dette, men en sentral faktor er den norske Grunnlovens jødeforbud, som var i kraft mellom 1814 og 1851 (Grunnloven 1814:§2). Folketellingen for 1900 viser at det bodde 642 jøder i Norge, hvorav 343 bodde i hovedstaden (Mendelsohn,1969:417). I 1910 var det samlede antall jøder i Norge steget til 1045, men på grunn av fødsler og dødsfall, var ikke tallet på nyinnvandrede jøder det siste tiåret mer enn omtrent 300 (434). Det er derfor snakk om en svært begrenset jødisk innvandring og minoritet i Norge. 
alder: Reisse, Mére, Dobe, Chaie, Selde, Feige og Alter. ${ }^{8}$ Etter hvert tilkommer ektefeller og barn av Goldes barn, i tillegg til venner og flyktninger som har en svært beskjeden plass i fremstillingen.

I 1929 ble jødisk slaktemåte forbudt i Norge. ${ }^{9}$ Familien diskuterer forbudet og sentrale aktører i debatten i etterkant (Scheer, 1948:224-227). De er tydelig oppskaket og bekymret over hvordan de nå skal få tak i koscher mat. ${ }^{10}$ Yngstebarnet Alter siterer en sterkt antisemittisk uttalelse av Bondepartietpolitikeren Jens Hundseid, senere norsk statsminister (1932-1933) og NSmedlem (1940-1945): "Vi har ingen forpliktelser til å utlevere våre husdyr til jødenes grusomheter, vi har ikke invitert jødene hit til landet, og vi har ingen forpliktelse til å skaffe jødene dyr til sine religiøse orgier!" (225). ${ }^{11}$ Golde forholder seg rolig, mens Alter er rasende: "Det er ikke bare det at de nekter oss å schächte [...], men det er den måten de snakker om oss på! Har vi ikke like stor rett til å leve som de andre?" (226).

Schächtingen er sentral for identiteten til religiøse jøder både som gruppe og individer. Jødiske spiseregler (kashrut) definerer maten som koscher, det som er lov til å spise, eller treif, ødelagt eller uren og derfor forbudt. Koscher mat og slaktemetode omtales i Mosebøkene, og reglene har i senere tid blitt utvidet og forklart av rabbinere. Overholdelsen av dem anses som en viktig del av pakten mellom Gud og det jødiske folket, og er en del av den religiøse loven (halakha), ifølge religionshistoriker Bente Groth (2011:107). Derfor er Goldes families reaksjon på den nye slakteloven naturlig. Alle mennesker må naturligvis ha mat for å leve, og schächtingen er således sentral for både livsgrunnlaget og identiteten til disse troende jødene. Ifølge Groth har mange jødiske lærde hevdet at "hensikten bak koscherlovene er å bevare nasjonens særpreg og hindre assimilasjon ved å trekke en grense mellom 'oss' og 'de andre" (108-109). Gjennom romanen får en inntrykk av at familien vi følger i størst mulig grad ønsker å tilpasse seg det norske samfunnet gjennom språk, arbeid, klesvalg og liknende, men det gjelder hovedsakelig deres opptreden utenfor hjemmet. Innenfor husets fire vegger fremstår familien i langt større grad opptatt av den jødiske identiteten. Et eksempel på dette og hvordan identiteten er forbundet med de religiøse spisereglene, diskuteres av to av søsknene, Feige og Alter, i tiende kapittel. Feige har nettopp oppdaget at søsteren Chaies ekteskap er i trøbbel, og vil høre hva Alter vet om saken. Alter forklarer at det begynte med at ektemannen hennes ville spise treif, men det ville ikke hun. Det er tydelig at Feige er enig med søsteren, men det er ikke Alter: "Herre Gud, Feige! Vi bor blant gojim [ikke-jøder], og lever og arbeider

${ }^{8}$ Se slektstavle i Scheer, 1948:285.

${ }^{9}$ Denne saken ble omtalt som "schächtingsaken". Se Snildal, 2014.

${ }^{10}$ Koscher betyr rituell mat (Scheer, 1948:283).

${ }^{11}$ Hundseid-sitatet er å lese i sin helhet i referatet fra forhandlinger i Odelstinget 12 . juni 1929:578. 
sammen med dem. Det er ikke lett å spise bare jødisk mat. Ikke kan jeg forstå at det skal være nødvendig heller. Det er vel ikke bare i matveien vi er jøder?" (Scheer, 1948:212). Det mener naturligvis ikke søsteren heller, men at det er viktig for henne, er tydelig. Feige lurer på om Alter spiser treif, og han svarer med en implisitt selvfølgelighet "[n]aturligvis!". På typisk søskenvis lurer søsteren på hva han tror moren ville synes om det, men Alter tror ikke moren ville bry seg, ettersom hun er "den fornuftigste av oss alle sammen" (213). For å trøste søsteren, som er trist på den andre søsterens vegne, sier han videre at det ikke er så sjelden folk skilles, men Feige mener at jøder ikke gjør det. Tilsynelatende oppgitt sier han: "Vi er først og fremst mennesker, Feige, ikke jøder...". Men det er ikke Feige helt enig i: "Jeg har aldri tenkt på det. For meg har det vært det samme å være menneske og jøde" (214-215). De avsluttende replikkene på samtalen sier mye om deres ulike syn på betydningen av den jødiske identiteten, eller hva det betyr for dem og deres identitet å være jøde, og må sees i sammenheng med betydningen av spisereglene. Feige kritiserer Alter for å ville være så moderne og fri, og mens spisereglene tydelig er svært viktige for resten av familiens identitet, er de mer eller mindre ubetydelige for ham. Det kan være flere årsaker til dette, som blant annet kjønnsrelaterte faktorer, men romanen gir ikke grunnlag for å gå nærmere inn på disse. Imidlertid kritiserer Alter Chaie for å være "akkurat som du [Feige] og de andre jentene, bare tenker på hva familien vil si" (214).

I henhold til hva Alexander skriver om forståelsen av identitet som en prosess, noe som formes i møtet mellom en (diaspora)kultur og en vertsnasjons kultur, kan Alters identitet tolkes som i større grad å være påvirket av vertsnasjonens kultur enn resten av familiens identitet. Den eneste av familiemedlemmene som viser like stor vilje og evne til å tilpasse seg vertskulturen, er Golde, som på grunn av sin høye(re) alder er sterkt preget av hjemlandets kulturelle koder, men likevel viser stor forståelse og åpenhet for "de unges" vilje eller evne til å la seg preges av vertsnasjonens kultur. Siden hybriditet kan forstås som det som skjer der hvor diaspora møter og interagerer med vertsnasjonen, og som et sted hvor nye kulturelle former og identiteter fremtrer, må likevel alt fra Alters og Goldes identiteter til Feiges, Chaies og ektemannens betegnes som kulturelt hybride identiteter.

I boken har Goldes kobber stor betydning for henne og familien. Det symboliserer både "hjem" og stabilitet og alt Måte-Mende og Golde har opplevd sammen. Deres identitet er derfor sterkt knyttet til kobberet de hele tiden har hatt hengende på veggen på kjøkkenet, og er begge svært stolte av det (Scheer, 1948:79). Kobberet representerer et fast holdepunkt, og der det befinner seg, der kan de finne seg til rette. Også i bestemoreventyret i Posene på gjerdestolpen ser vi at kobberet er viktig for Golde: "På den ene veggen var det fullt av skinnende blankt kobber, bestemoren pusset det hver uke og hang en gammel gardin over så det skulle holde seg fint til sabatten [sic]" (Scheer, 
1977:11). I Vi bygger $i$ sand kommer betydningen av det blant annet frem ved at Måte-Mende, like etter han er kommet til Kristiania, uttrykker hvor mye han gleder seg til Golde kommer og hvor fint de skal få det "når hun får alt kopperet og messingen på veggen". Kobberet symboliserer også Goldes styrke og utholdenhet, og forteller leseren mye om hvem hun er, hvilket fremgår av en samtale mellom Måte-Mende og svigersønnen. Izik mener det ikke er sikkert hun făr det med seg over grensen, men da svarer Måte-Mende vantro:

Er du meschugge [skrullete/gal]! Kopperet og messingen reiser ikke Golde fra! Det har hun hatt med seg fra Samelan til Libau, fra Libau til Argentina, tilbake til Samelan og til Morowjow. Tror du virkelig ikke at Golde får det med seg over grensen? Da kjenner du henne dårlig (Scheer, 1948:117).

Språket i Vi bygger $i$ sand er særegent idet det bærer preg av både Scheers og romanfigurenes jødiske bakgrunn og tradisjoner fra shtetlmiljøet. Boken er skrevet på norsk med jevnlige innslag av jiddische ord som tilfører boken en særegen stemning uten sidestykke i norsk litteraturhistorie. Som lesere kommer vi nærmere innpå den jødiske og jiddische (språk)kulturen gjennom dette fortellertekniske grepet. Virkemiddelet underbygger dermed også migrasjons- og minoritetsperspektivet i romanen. Miljøet og kulturen som skildres i boken fremstår som inkluderende. Dette kommer også til uttrykk gjennom bokens struktur ved hjelp av forfatterens ordliste bakerst i boken, som sørger for at leseren ikke faller fra i språklig forvirring eller ekskludering underveis. ${ }^{12}$ Språket er derfor viktig, som et bearbeidet litterært grep og delvis også som emne i romanen. Gjennom det litterære språket får leseren følelsen av å få ta del i et autentisk norsk-jødisk miljø. Språket er samtidig en viktig identitetsmarkør, både i den betydning at det markerer en norsk-jødisk gruppeidentitet for leseren og i den betydning at det bidrar til å forsterke en innbyrdes gruppeidentitet innad i det norsk-jødiske miljøet i romanen.

La oss dvele et øyeblikk ved tittelvalget. I en "dagboknotis" presiserer Scheer at "boken heter 'Vi bygger i sand' - (ikke påa sand, men $\underline{i})$ " (dokument merket "Møtet 23/11.-87.", i JMO.D00387, min kursivering). Dette vitner om at forfatteren har vært seg meget bevisst tittelvalget og tillegger tittelen en særlig betydning. Ut fra romanens handling fremgår det også tydelig hva hun legger i den. Golde og Måte-Mende forsøker å skape et trygt og godt liv for seg og sin familie, og dette fører dem langt hjemmefra. Vi bygger $i$ sand er en metafor for den jødiske familiens livsvilkår - både i tsarriket, Argentina og til slutt i Norge. Selv om livet der lenge er mye bedre enn det livet de tidligere har levd, er det nettopp her mange av dem skal møte sin skjebne (gjennom arrestasjoner og deportasjon høsten 1942). Metaforen går derfor i at de forsøker å bygge seg et liv på trygg grunn. Tittelen kan også være en allusjon til

${ }^{12}$ Se "Ordliste" i Scheer, 1948:283-284. 
Matteusevangeliet og lignelsen "Huset bygd på fjell" (Matt 7:24-29). Det er i så fall interessant at Scheer har valgt en lignelse fra den kristne teksten Det nye testamente, ikke minst $i$ lys av Vi bygger $i$ sands tematisering av kulturmøtet mellom en østeuropeisk-jødisk og norsk-kristen kultur. Lignelsen forteller at det er klokt å bygge hus på fjell og uforstandig å bygge hus på sand. Ved å velge preposisjonen $i$ i tittelen, formidler Scheer at bokens personer, som jøder, er henvist til et liv på ustø grunn, og unngår samtidig at de i henhold til kristen tradisjon fremstår som uforstandige; for de har ikke bygget $p a ̊$ sand, de har bygget $i$ sand. Den valgte preposisjonen understreker dessuten enda tydeligere grunnens karakter; de er allerede nedsunkne i sanden før de starter byggingen av et nytt liv. Tittelen har en tydelig tilknytning til narrativets avslutning og foregriper den. For det er med avslutningen tittelen kommer til sin rett og blir sannhet: Idet Golde og så mange av hennes familiemedlemmer går over landgangen til Donau, er deres skjebne forseglet, og alt de har jobbet for gjennom et langt liv, har vært forgjeves. ${ }^{13}$

Det er særlig Goldes små barn som møter problemer i det norske samfunnet. Ett eksempel finner sted den sommeren Golde og barna ankommer Norge (foruten Mére og Reisse som ankom tidligere). På dette tidspunktet snakker de fremdeles ikke norsk, og for barna, som vil leke med andre barn i nærområdet, byr dette på problemer. I en episode som skildres, leker de sisten. Chaie kommer i konflikt med en gutt som heter Thorleif, fordi hun holder ham for hardt. Chaie, som heller ikke snakker norsk, forstår ikke hva han mener når han roper "slepp", for på jiddisch betyr det det motsatte av på norsk, nemlig "dra". Både Thorleifs mor og Chaies eldre søster Reisse får med seg oppstyret fra vinduene sine, og de to barna sladrer på hvert sitt språk. Humoristisk skildres språkproblemene og hvordan Reisse blir tolk og mekler i denne situasjonen (Scheer, 1948:139). ${ }^{14}$ Etter dette ville ikke de norske barna leke med Goldes barn lenger, og ropte jøde til dem. Dette forstod de riktignok ikke, men det må tolkes som bruken av ordet jøde som skjellsord, og som utslag av antisemittisme i det norske samfunnet.

Både romankarakterenes problemer $\mathrm{i}$ det nye vertslandet og spenningskurven når sitt høydepunkt med jødeforfølgelsene i Norge høsten 1942. Det er også her romanen avsluttes: Med Goldes og familiens ombordstigning i lasteskipet Donau, som skulle føre dem til en ukjent destinasjon og skjebne. De siste to-tre kapitlene av boken er preget av en stadig mer klemmende stemning

13 Alle jødiske norske menn over 15 år ble arrestert og internert 26. oktober 1942. Mennene fra Østlandet havnet hovedsakelig på Berg leir utenfor Tønsberg. De jødiske mennene forble arrestert frem til deportasjonen med Donau fra Oslo, til den tyske konsentrasjonsleiren Auschwitz, 26. november 1942 (Bruland, 2017:241, 258, 265-276).

${ }^{14}$ Når Chaie og Dobe begynner på skolen om høsten, blir språkproblemene et enda større problem, særlig for Dobe som er eldst, og som i tillegg sliter med skammen knyttet til at hun er så mye eldre enn de andre barna (Scheer, 1948:140). 
i den jødiske minoriteten i hovedstaden. ${ }^{15}$ Og mens de norske nasjonalsosialistene strammer grepet om den jødiske befolkningen, blir romankarakterenes jødiske identitet stadig tydeligere for dem; med en stor, rød $\mathrm{J}$ stemplet $\mathrm{i}$ identitetspapirene, er det ingen måte å unnslippe deres jødiske bakgrunn, uavhengig av tro. Det er etnisiteten, eller "rasen", som betyr noe. Samtidig blir romankarakterene mer opptatt av sin jødiske identitet enn noen gang tidligere: Kvinnene samles om å hjelpe hverandre og mennene, som blir arrestert 26. oktober. Minoriteten holder sammen. Boken sier ingenting om hvordan det går med Golde og hennes familie etter den tvungne deportasjonen. Men historien forteller oss at alle norsk-jødiske kvinner, barn og eldre ble sendt direkte i gasskammeret ved ankomst til Auschwitz 1. desember 1942, og at de fleste av mennene døde av utmattelse og sykdommer eller på andre måter ble pint $\mathrm{i}$ hjel etter svært kort tid i konsentrasjonsleirene (Bruland, 2017:594-595). ${ }^{16}$ Historien er av sentral betydning her, særlig med hensyn til at Vi bygger $i$ sand ble utgitt kun tre år etter verdenskrigens slutt.

\subsection{BYGGER I SAND SOM MINORITETSROMAN}

Scheer forsøker gjennom kollektivromanen og dens synsvinkel å synliggjøre perspektivet til det vi kan kalle den dominerte immigrant. I tillegg til at romanen kan kalles en migrasjonsroman, kan den også kalles en minoritetsroman. Dette skyldes at den skildrer en minoritets opplevelser i møte med et majoritetssamfunn. I 1851 ble jødeparagrafen og forbudet mot jødisk innvandring til Norge opphevet. Dette medførte en formell likestilling av jøder med ikkejødiske norske borgere. I realiteten var saken imidlertid ikke fullt så enkel. I styrkeforholdet mellom de etablerte nordmennene og de nyankomne jødene som var fattige og ikke kjente språket, er det ingen tvil om at sistnevnte var den underlegne part. Det er i dette perspektivet postkolonial teori viser seg fruktbar for den foreliggende analysen. Jødene har som minoritet vært utsatt for nordmenns representasjoner av dem gjennom stereotypier. Dette innebærer med andre ord at jødene er blitt tillagt egenskaper nordmenn mener de har. Et viktig poeng i denne sammenhengen er at svært få nordmenn noen gang hadde møtt en jødisk person. ${ }^{17}$ Dette innebærer at jødeforakt hovedsakelig må være et resultat av representasjon og fordommer. I norsk kontekst har dette i likhet med $\mathrm{i}$ forholdet mellom kolonister og koloniserte ført til en polarisering

${ }^{15}$ Leseren med historisk kunnskap håper intenst at familien skal skånes fra det som skulle bli skjebnen til 475 av hovedstadens jødiske individer, hvorav kun 20 skulle returnere (Bruland, 2017:365).

${ }^{16}$ Av de femten familiemedlemmene til Eva Scheer som ble deportert, var det ingen som overlevde (Wåle, 1967:18). 2014:253).

${ }^{17}$ Den jødiske minoriteten i Norge har på det meste offisielt hatt 1457 medlemmer (Søbye, 
mellom det norske subjektet, "vi", og "jøden", "den andre", slik Edward Said beskriver det (2003:1, 45-46). Ett siktemål med postkolonial kritikk er å illustrere og analysere utøvelse av kulturell makt, eller det Said omtaler som orientalisme (40). På mange måter er også antisemittisme og fordommer mot jøder utøvelse av kulturell makt; jødene har i århundrer vært en minoritet $\mathrm{i}$ Europa, og den kristne majoriteten har på alle områder marginalisert dem (xviii). Det jødiske samfunnet har til alle tider blitt holdt kollektivt ansvarlig for de egenskapene som kjennetegner enkelte medlemmer av gruppen (Berg Eriksen et al., 2009:137). Det er nettopp generaliseringer fra enkeltindividet til gruppen som helhet som danner utgangspunktet for stereotype oppfatninger og fordommer. Felles for Orienten, koloniserte stater og jødene er at de har befunnet seg $\mathrm{i}$ en underlegen posisjon i forhold til Vestens, og det norske majoritetssamfunnets (i denne spesifikke konteksten), hegemoni på alle samfunnsområder; Norge har utøvet makt over jødene, slik Vesten har utøvet makt over Orienten og kolonistater har utøvet makt over koloniserte stater.

I forholdet mellom jødene og den norske kulturen finner vi derfor postkoloniale elementer i romanen. Et sentralt begrep her er Homi K. Bhabhas mimicry. I essayet "Of mimicry and man. The ambivalence of colonial discourse" (i The Location of Culture fra 1994) definerer Bhabha kolonialisme som ambivalent: Kolonistene fremhever de kolonisertes annerledeshet, men reduserer dem samtidig til noe gjenkjennelig gjennom stereotypier. Kolonialisme både fremmer og hemmer dermed forskjellen mellom det koloniale subjektet og den koloniserte andre. Når den koloniserte assimilerer kolonialistens kjennetegn og imiterer dennes oppførsel, vaner eller normer, kaller Bhabha dette for mimicry. Mimicry er en av de mest effektive og flyktige strategiene til kolonial makt, og gjennom mimicry blir den koloniserte "almost the same, but not quite" (Bhabha, 1994:85, 86, uthevelse i original). "Mimicry repeats rather than re-presents" (88).

Det eksisterer tydelige paralleller mellom mekanismene som styrer forholdet mellom kolonister og koloniserte og mekanismene som styrer forholdet mellom en majoritetsbefolkning og en minoritetsbefolkning $i$ et historisk perspektiv. Det eksisterer også forskjeller, som at det kan virke skremmende og potensielt traumatiserende på en helt annet måte å få sitt land invadert av en fremmed makt som fra det tidspunktet skal sette dagsorden, enn selv frivillig å migrere til et nytt land som har sine (fremmede) levemåter og regler; men dette minimerer ikke betydningen av likhetene mellom de sentrale prosessene som ligger til grunn for forholdet mellom det vi kan kalle en dominerende makt og en underlegen part. Felles for de koloniserte og jødene i diaspora er at begge er marginaliserte grupper i samfunnet. I den foreliggende romanen er det altså slik at romankarakterene har migrert til Norge frivillig. Som jøder er Golde med familie vant til å være betraktet som en slags annenrangs borgere i Russland, og tilsynelatende forventer hun heller ikke å 
bli noe annet i Norge. Det hun imidlertid forventer, eller i alle fall ønsker, er større trygghet for seg og sin familie ("vi må vekk fra dette helvetet, la oss komme oss vekk. [...] Vi kan ikke leve i Russland. Tenk på barna våre") (Scheer, 1948:121-122).

I Vi bygger $i$ sand er Rolf, Feiges beiler, en sentral målbærer av nordmenns fordommer mot jøder. Vi finner mange eksempler på dette i en samtale mellom ham og Feige. For eksempel sier han: "Du kan ikke se bort fra at dere har noe skyld i antisemittismen selv, Feige. Det er ikke tilfeldig at jødene blir forfulgt [...] dere isolerer dere. Dere har bygd en stor mur rundt dere". Et annet eksempel fra samme samtale er dette: "[...] Jeg kjente ingen jøder før jeg traff deg og dine, derfor har det aldri vært noe problem for meg. Hvis alle jøder hadde vært som dere er, ville det ikke vært noe jødeproblem." Feige tar denne replikken ille opp, for det er en utbredt holdning Rolf gir uttrykk for her: "Det er det aller verste du kan si til oss, Rolf. Det rare er at alle jøder hører det av sine venner. 'Hvis alle hadde vært som du er' eller 'Jeg liker deg, du er ikke som andre jøder'. Forstår dere ikke at dere sårer oss med å si det? [...]". Og Rolf svarer: "[...] Nei, saken er vel den at vi ikke vet noe om dere. Alt fremmed virker mystisk, tildels farlig, vet du. Dere er fremmede, og har andre skikker" (Scheer, 1948:230). Gjennom denne siste replikken til Rolf synliggjøres det postkoloniale perspektivet i romanen: "Nei, saken er vel den at $v i$ [nordmenn] ikke vet noe om dere [jøder]" - likevel uttrykker han tydelig at både han og andre nordmenn har klare meninger om jøder (min utheving): Jødene har noe av skylden for antisemittismen selv, det er ikke tilfeldig at de blir forfulgt og de isolerer seg. I mer diffuse ordelag uttrykker han også at Feige og hennes familie ikke er som andre jøder; implisitt sier han at de er bedre enn dem. Likevel innrømmer han eksplisitt at han ikke kjenner noen andre jøder enn Feige og familien hennes. Så hvem eller hva sammenlikner han dem da med? Her blir det tydelig at Rolf i likhet med kolonistene fremhever jødenes annerledeshet og samtidig, om enn indirekte, reduserer dem til stereotypier (Bhabha, 1994:85-86). Slik opplever også Feige selv det, noe hun senere i diskusjonen poengterer: "[...] Det blir sagt så meget om oss. Vi skal være feige heter det, vi har mange penger, vi holder oss unna krigen og tjener på den. Det er bare tull [...]" (Scheer, 1948:233). Men hun spør også: "Synes du virkelig at det livet jeg fører er så fremmed for deg at det virker 'farlig'?", hvorpå Rolf svarer: "Nei. Ikke du" (231). Indirekte fremkommer det her at Rolf, som representant for det norske, både fremmer og hemmer forskjellen mellom nordmenn og jødene, slik også tilfellet er for kolonialisten og det vestlige subjektet overfor den koloniserte og orientaleren. Feige og hennes familie, som er assimilert og særlig utenfor hjemmet imiterer nordmenns oppførsel, vaner og normer, er derfor underlagt den mekanismen Bhabha kaller mimicry. For som Bhabha påpeker, blir den kolonialiserte, i dette tilfellet Goldes familie, gjennom mimicry "almost the same, but not 
quite", et syn det er tydelig at Rolf deler (Bhabha, 1994:86, uthevelse i original).

Videre i samtalen diskuterer Rolf og Feige om det finnes antisemittisme i Norge, og de er sterkt uenige. Han mener det aldri vil bli "noen antisemittisme av betydning" her: "[...] Er dere ikke borgere av landet med de samme rettighetene som nordmenn?". Men det er nettopp slike uttalelser som understreker poenget hennes: 'Der kan du se selv! Du snakker om 'dere' og 'nordmenn'. Er ikke vi nordmenn? Vi er jo borgere av landet. Hvorfor snakker du om nordmenn og jøder, istedenfor å snakke om norske jøder og ikkejøder?" (Scheer, 1948:231). Hun krever med andre ord å bli behandlet likt som ikke-jødiske nordmenn og ikke minst å bli betraktet som norsk på linje med andre, samtidig som Rolf understreker sitt "orientalistiske" syn på skillet mellom "oss" og "dem". Bhabha hevder at det hefter en tvetydighet ved mimicry som kommer til uttrykk ved at den kolonisertes eller undertryktes miming kan avsløre noe ved kolonisten eller den undertrykkende. Dette subversive potensialet som ligger i konseptet mimicry gjør seg dermed gjeldende i diskusjonen mellom Rolf og Feige, for gjennom imitasjonen av nordmenn og ved å anse seg som norsk, avslører Feige Rolfs fordommer, som han ikke er klar over at han har.

Det er tydelig at Feige hverken oppfatter seg selv som "helt" norsk eller "helt" jødisk, slik det fremgår av det foregående. I The Location of Culture (1994) illustrerer Homi Bhabha noen muligheter med begrepet hybriditet, som han også beskriver som det tredje rommet ("the Third Space"). Bhabha mener ikke at det tredje rommet er en kombinasjon av to kulturelle områder eller identiteter som danner en ny enhet, men at det innebærer noe radikalt annerledes som bryter med enhetlige kategorier (Bhabha, 1994:36-39). Det tredje rommet er rommet imellom, "the in-between space" (38). Ifølge Bhabha krever tolkningen av meningsproduksjon mellom en avsender og en mottaker et tredje rom som representerer både de generelle språkforhold og den spesifikke implikasjonen av ytringen. Denne ubevisste relasjonen introduserer eller medfører en ambivalens i tolkningen (36). Det er i dette tredje rommet alle kulturelle utsagn og systemer konstrueres, og det er først når vi forstår dette, at vi kan forstå hvorfor hierarkiske inndelinger av ulike kulturers verdi er uholdbar (37). Hybriditet beskrives likeledes som en tilstand av in-between, eller "imellomhet" (13). Bhabha fremmer et syn hvor hybriditet representerer en positiv utvikling, for det er gjennom den at "newness enters the world", som Bhabhas essay "How Newness Enters the World. Postmodern space, postcolonial times and the trials of cultural translation" indikerer.

Feige-karakteren belyser hvordan jødene befinner seg i en slags mellomposisjon, en hverken-eller og samtidig "almost the same, but not quite" (Bhabha, 1994:86, uthevelse i original). Jødene som kommer til Norge forsøker å lære seg språket og tilpasse seg norsk kultur og levemåte, men det 
tar tid å "bli norsk". Denne kulturelle hybride væremåten som hverken er strengt jødisk eller strengt norsk, ser dessuten ut til å irritere nordmenn: ${ }^{18}$

[...] Dere lar dere irritere av språket vårt. Mange er kommet voksne til landet og snakker gebrokkent. Det er blitt en egen form for humor, alle disse vitsene med gebrokkent snakk om Isak. Ungene roper: 'Jøde, dra til Palestina!' etter oss. Tenk deg selv en nordmann som reiser til Kina og bosetter seg der. Han blir ikke kineser med en gang. Han kan aldri bli vaskeekte kineser, fordi han har en annen religion og lyst hår. - Vi har mørkt hår og en annen religion, derfor blir vi ikke 'norske' her så fort"' (Scheer, 1948:232). ${ }^{19}$

Utslag av antisemittisme er gjennomgående i romanen; familien møter fiendtlighet både i tsar-Russland og i Norge. Blant annet beskrives flere tilfeller hvor andre barn roper jøde til Goldes barn, og ikke minst vitner flere av Måte-Mendes og Iziks erfaringer fra omførselshandelen i landet om fiendtlige holdninger i den norske befolkningen. Blant annet kalles Izik for "Jøden" og Måte-Mende for "Gamle-Jøden" når de reiser rundt, og flere ganger blir de "skjelt ut for jøder og pakk", eller får hunder sendt ut etter seg $(134,136)$. Måte-Mende passer på å vektlegge de positive erfaringene når han forteller de nyankomne familiemedlemmene om Norge, men nevner ikke noe om utslagene av jødefiendtlighet. Også andre former for fordommer og antisemittisme forekommer i romanen, som at alle bønder er sikre på at jødene snyter dem: "Alle jøder jokser [sic], sier de" (135). Jødefiendtligheten i det norske samfunnet når sitt høydepunkt med hendelsene som beskrives høsten 1942.

\section{AVSLUTNING}

Hadde familien tenkt at landflyktigheten var av en midlertidig karakter og at de en dag skulle reise tilbake til Russland, kunne dette ha stått i veien for integrasjon og utviklingen av kulturelt hybride identiteter. Det gjør det imidlertid ikke. Familien har kommet til Norge for å bli, og ønsker å tilpasse seg, de ønsker å "bli norske". Innenfor romanens normsystem lykkes det dem imidlertid ikke; de kan ikke bli "helt norske" så lenge de også bevarer sin jødiske identitet. Tilsynelatende fortsetter nordmennene å anse dem som "almost the same, but not quite", uansett hva romanfigurene foretar seg (Bhabha, 1994:86, uthevelse i original). Dette nedvurderende blikket på jødene kulminerer med avslutningen av romanen høsten 1942, hvor Golde og så mange av hennes familiemedlemmer går en skrekkelig skjebne imøte.

${ }^{18}$ Om noe slikt som "strengt jødisk" og "strengt norsk" eksisterer, kan selvsagt diskuteres, men det er ikke rom for å gå videre inn på dette her.

${ }^{19}$ For å lese mer om jødefiendtlig bruk av gebrokken tale som komisk virkemiddel, se blant annet Lien, 2015 og Brovold, 2016. 
Uten selv å være riktig klar over det, utvikler romankarakterene kulturelt hybride identiteter som et resultat av møtet mellom deres gamle identitet formet av livet $i$ shtetelen og i Argentina og kravene om en ny identitet $i$ vertskulturen Norge. Som det fremgår av betydningen av kashrut (spisereglene) for enkelte av romankarakterenes identitet, er de som andre familier forskjellige. På grunn av romanens utforming som kollektivroman, er det ikke mulig å si noe om hver enkelt av romankarakterenes identitet og selvforståelse. Det er likevel svært interessant å se hva romanen sier sammenfattet om deres forståelse og utvikling av identitet i løpet av handlingen, ikke minst på grunn av romanens særstilling i norsk litteraturhistorie. Romanens biografiske karakter og forfatterens nærhet til det fortalte muliggjør bruken av fremstillingen som historisk kilde til de omtalte begivenhetene. Her tenker jeg ikke minst på usikkerhet eller problemer knyttet til forståelsen av egen identitet for jøder i Norge med minoritetsbakgrunn i det aktuelle tidsrommet.

Den foregående analysen fremstiller sentrale trekk ved migrasjonserfaringen til romankarakterene, som etter alt å dømme har en rekke fellestrekk. Oppfattelsen av identitet og graden av identitetsproblematikk er den mest private, intime og subjektive av de omtalte migrasjonserfaringene, og derfor umulig å beskrive utfyllende innenfor de gitte rammene. Erfaringene knyttet til en mer negativ form for samhandling med andre (primært nordmenn), er i langt større grad homogen, og inkluderer opplevelsen av fordommer, antisemittisme og frykt for jødeforfølgelser. For romankarakterene innebærer migrasjonen til Norge større trygghet fra jødeforfølgelser (frem til 1942) og etter hvert en tryggere og bedre økonomi. Migrasjonserfaringen påvirker andregenerasjonsinnvandrernes identitetsforståelse på ulike måter, som det fremgår av samtalen mellom Alter og Feige. Dette er det tydeligste stedet $\mathrm{i}$ fremstillingen oppfattelsen av identitet kommer til uttrykk. Vi bygger $i$ sand tar slik opp mange interessante spørsmål knyttet til migrasjonserfaring. Hva skal til for å tilhøre en nasjon? Hva skal til for å bli norsk? Med de siste tiårenes sterkt endrede migrasjonsmønster gjør slike problemstillinger romanen dagsaktuell. I likhet med flere av romankarakterene i Scheers bok, ønsker mange migranter å bevare sin gamle kultur samtidig som de ønsker å tilpasse seg vertslandets. Hvordan være norsk når man også har en annen kulturell bakgrunn?

\section{LITTERATUR}

Alexander, C. (2010). Diaspora and hybridity. I: Hill Collins, P. \& J. Solomos (red.). The Sage Handbook of Race and Ethnic Studies (s. 487-507). London: Sage Publications.

Andersen, P. T. (2001). Norsk litteraturhistorie. Oslo: Universitetsforlaget. 
Arbeiderbladet. (1948). Vi er nordmenn. Arbeiderbladet 3. november 1948: 2. https://beta.nb.no/items/

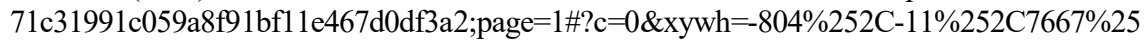
$2 \mathrm{C} 4223 \& \mathrm{cv}=1$

Berg Eriksen, T. et al. (2009). Jødehat. Antisemittismens historie fra antikken til i dag. Oslo: Cappelen Damm AS.

Berthelsen, H. (red.). (1987). Scheer, Eva. Hvem er hvem i norsk kulturliv?, 369-370. Dreyer. http://www.nb.no/nbsok/nb/5bc1b6bb658961cbb8aedbe369fe88d3?index=2\#369

Bhabha, H. K. (1994). The Location of Culture. London and New York: Routledge.

Bingen, A. (1987). Evas jødiske bestemor ble sendt i døden. Nationen, 30. desember 1987: 14-15. https://beta.nb.no/items/bfbd9270fddb0a49b54630fecab3b6df;page $=13 \#$ ?c $=0 \& \mathrm{~m}=0 \& \mathrm{~s}=0 \& \mathrm{cv}=$ $13 \&$ xywh $=-2675 \% 252 \mathrm{C} 397 \% 252 \mathrm{C} 12701 \% 252 \mathrm{C} 5729$

Borgen, J. (1977). Jødisk kosekrok - 1/2G Ertekrok. Dagbladet 31. mai 1977: 4. https://beta.nb.no/items/ f0531dec8a5a8d6c654c449b2984f160;page $=3 \#$ ?c $=0 \& x y w h=515 \% 252 \mathrm{C} 3879 \% 252 \mathrm{C} 5700 \%$ $252 \mathrm{C} 3140$

Brekke, P. (1948). Jøder i Norge. Dagbladet, 26. november 1948: 5. 28. juli 2017: https://beta.nb.no/items/d3920fd12cdca923b5e9678505054269;page $=4 \# ? \mathrm{c}=0 \& \mathrm{~m}=0 \& \mathrm{~s}=0 \& \mathrm{c}$ $\mathrm{v}=4 \& \mathrm{xywh}=-3613 \% 252 \mathrm{C} 0 \% 252 \mathrm{C} 18639 \% 252 \mathrm{C} 8407$

Brovold, M. M. (2016). De første jødene. Norsk dramatikk 1825-1852. Masteroppgave, Universitetet i Oslo.

Bruland, B. (2017). Holocaust i Norge. Registrering, deportasjon, tilintetgjørelse. Oslo: Dreyers forlag.

Dagbladet. (1948). Norge sett med jødiske immigranters øyne. Dagbladet, 12. oktober 1948: 5. http://www.nb.no/nbsok/nb/31db80ab765214aa03cfe122e49bfa06?index $=6 \# 3$

Dagbladet. (1948). Jødenes skjebne belyst i slektsroman. Dagbladet, 2. november 1948: 3. https://beta.nb.no/items/4955aa29252ea0c6f1056e 86fd8eca0e;page $=2 \# ? \mathrm{c}=0 \& \mathrm{~m}=0 \& \mathrm{~s}=0 \& \mathrm{c}$ $\mathrm{v}=2 \& \mathrm{xywh}=9575 \% 252 \mathrm{C} 1837 \% 252 \mathrm{C} 3345 \% 252 \mathrm{C} 1508$

Dworsky, I., O. Mendelsohn og E. Scheer. (1959). Jødisk Ungdomsforening Oslo. Festskrift ved 50-årsjubiléet. Sandvika: "Budstikken"s trykkeri.

Flottorp, H. (1977). Eva Scheers jødiske eventyr. Fcedrelandsvennen, 21. juli 1977: 2. http://www.nb.no/nbsok/nb/b97b634f783e899aaaf0f37939965f10?index=7\#0

Flottorp, H. (1981). Jødisk fortellerkunst på sitt beste: Ut av ghettoen. Fcedrelandsvennen, 2. november 1981: 6 . https://beta.nb.no/items/2aa4907a0780f778d1ae14c929ee26a1;page= $5 \# ? \mathrm{c}=0 \& \mathrm{~m}=0 \& \mathrm{~s}=0 \& \mathrm{cv}=5 \& \mathrm{xywh}=1732 \% 252 \mathrm{C} 2205 \% 252 \mathrm{C} 4094 \% 252 \mathrm{C} 1844$

Frank, S. (2008). Migration and Literature. Günter Grass, Milan Kundera, Salman Rushdie, and Jan Kjarstad. London and New York: Palgrave Macmillan.

Groth, B. (2011). Jødedommen. Oslo: Pax forlag.

Grunnloven. (1814). Kongeriget Norges Grundlov. https://lovdata.no/dokument/HIST/lov/181405-17-18140517

Houm, P. (1955). Norges litteratur fra 1914 til 1950-årene. I: Bull, Francis (red.). Bind 6 av Norsk litteraturhistorie, Oslo: H. Aschehoug \& Co.

Johansen, J. O. (1979). En død kultur som er levende. Dagbladet 4. oktober 1979: 15. https://beta.nb.no/items/2b4992fce19ef020264a051be141e5cb;page $=14 \#$ ?c $=0 \& x y w h=428$ $4 \% 252 \mathrm{C} 5969 \% 252 \mathrm{C} 4821 \% 252 \mathrm{C} 2656 \& \mathrm{cv}=14$

Johansen, J. O. (1981). For folk med seksualangst. Dagbladet, 25. august 1981: 5. https://beta.nb.no/items/3f8d144345bed62d4cf937dcd55fd15a;page=6\#?c=0\&xywh=7192 $\% 252 \mathrm{C} 612 \% 252 \mathrm{C} 3379 \% 252 \mathrm{C} 1861 \& \mathrm{cv}=6$

Johansen, J. O. (1982). Lavmælt, gjennomtrengende. Dagbladet, 28. oktober 1982: 16. https://www.nb.no/items/8713297c957b81938a3be2c85ed2eeff?page $=15 \&$ searchText $=\% 2$ 2Lavm\%C3\%A6lt,\%20gjennomtrengende\%22

Johansen, J. O. (1983). En frodig kultur. Dagbladet 15. september 1983: 4. https://beta.nb.no/items/78f73d7125f2e4de48bdf955c51cc17e;page $=3 \#$ ?c $=0 \& x y w h=-$ $253 \% 252 \mathrm{C}-202 \% 252 \mathrm{C} 4901 \% 252 \mathrm{C} 2700$ 
Lange-Nielsen, S. (1977). Jødiske eventyr. Aftenposten, 15. juni 1977: 7. http://www.nb.no/nbsok/nb/4bffcdad0dc05470c0c4feaf59438143?index=14\#5

Larsen, T. (2015). Historier fra et jødisk kjøkken. Dagsavisen, 10. juni 2015. http://www.dagsavisen.no/kultur/boker/historier-fra-et-jodisk-kjokken-1.365320

Lien, L. (2015). '...pressen kan kun skrive ondt om jøderne'. Jøden som kulturellkonstruksjon i norsk dags- og vittighetspresse 1905-1925. Doktorgradsavhandling, Universitetet i Oslo.

Me. (1948). En bok som angår oss alle. Sarpsborg arbeiderblad, 29. november 1948: 2. http://www.nb.no/nbsok/nb/1784c76e0854a3a585a2273e53c70979?index=3\#1

Mendelsohn, O. (1969). Jødenes historie $i$ Norge gjennom 300 år. Bind 1. Oslo: Universitetsforlaget.

Nationen. (1977). Rekordstor bokliste fra Luther. Nationen, 18. mars 1977: 12. http://www.nb.no/nbsok/nb/f0fa9b33dc003cc1ad6332a19ba870b4?index=12\#11

Nordal, K. W. (1951). Det lovede land. Eva Scheer: Vi møttes i Jerusalem. Tiden. Arbeiderbladet, 6. november 1951, 63, (258): 2. https://beta.nb.no/items/1cb33fb719538 $4 \mathrm{~cd} 4 \mathrm{c} 5 \mathrm{c} 3 \mathrm{~b} 5 \mathrm{~d} 5 \mathrm{a} 6 \mathrm{da} 6 \mathrm{ef}$ ?page $=1$

Odelstinget. (1929). 12. juni 1929. Forhandlinger i Odelstinget (nr. 73). 1929. Efterm. 12. juni Lov om avlivning av husdyr og tamren: 577-584. https://www.stortinget.no/no/Saker-ogpublikasjoner/Stortingsforhandlinger/Lesevisning/?p=1929\&paid=8\&wid=a\&psid=DIVL2 64

Pedersen, B. E. (2015). Løfter fram jødisk Oslo-stemme. Dagsavisen, 10. juni 2015: 40-41. 28. juli 2017: https://beta.nb.no/items/75b1032537a6a4aa5dbfe9baa19477d9;page=39\#?c= $0 \& \mathrm{~m}=0 \& \mathrm{~s}=0 \& \mathrm{cv}=39 \& \mathrm{xywh}=-353 \% 252 \mathrm{C}-28 \% 252 \mathrm{C} 7279 \% 252 \mathrm{C} 3283$

Rana Blad. (1948). Norsk immigrantroman. 22. november 1948: 3. https://beta.nb.no/items/ a6e0feb1 f697d61 ef $21 \mathrm{dbb} 3 \mathrm{e} 01$ ef66b6;page $=2-? \mathrm{c}=0 \& \mathrm{~m}=0 \& \mathrm{~s}=0 \& \mathrm{cv}=2 \& \mathrm{xywh}=4542 \% 252$ C5587\%252C6293\%252C2835

Rana Blad. (1951). Reiseskildring fra Israel. Rana Blad, 14. november 1951: 4. https://beta.nb.no/items/d47d2db42fc059489d9c861fd8d31983;page $=3 \# ? \mathrm{c}=0 \& \mathrm{~m}=0 \& \mathrm{~s}=0 \&$ $\mathrm{cv}=3 \& \mathrm{xywh}=-1 \% 252 \mathrm{C} 1621 \% 252 \mathrm{C} 5814 \% 252 \mathrm{C} 2619$

Rothlauf, G. (2009). Vom Schtetl zum Polarkreis. Juden und Judentum in der norwegischen Literatur. Doktorgradsavhandling, Universität Wien. http://othes.univie.ac.at/7021/1/200909-28_6925001.pdf

Rønning, A. B. (1990). I dialog med fortiden. Den nye historiske romanen. I: Engelstad, Irene et al. (red.). Bind 3: 1940-1980 av Norsk kvinnelitteraturhistorie. (s. 68-77).Oslo: Pax.

Said, E. W. (2003). Orientalism [1978]. London: Penguin Books.

Sarpsborg Arbeiderblad. (1948). 'Jeg er jødinne'. Sarpsborg Arbeiderblad, 16. november 1948: 5. http://www.nb.no/nbsok/nb/e43294b023e42e2775ca17a8d24119ef?index=14\#3

Scheer, E. (1948). Vi bygger $i$ sand. Oslo: Tiden norsk forlag.

Scheer, E. (1977). Posene på gjerdestolpen. Jødiske sagn og eventyr. Oslo: Luther forlag.

Scheer, E. (1979). Papirbroen. Jødisk drøm og virkelighet. Oslo: Luther forlag.

Scheer, E. (1981). Tre er fedrene, fire mødrene. Oslo: H. Aschehoug \& Co.

Sejersted, J. M. (2003). Norsk migrasjonslitteratur. Norsk littercer årbok (s. 80-100). Oslo: Samlaget.

Snildal, A. (2014). An Anti-Semitic Slaughter Law? The Origins of the Norwegian Prohibition of Jewish Religious Slaughter c. 1890-1930. PhD-avhandling, Universitetet i Oslo.

Surén, O. W. (2015). Forteljinga om mennesket. Dag og Tid, 3. juli 2015: 30. https://beta.nb.no/items/2b385b7aab3ef7c16a0ab95eb8109ae5;page $=29 \#$ ? $\mathrm{c}=0 \& \mathrm{~m}=0 \& \mathrm{~s}=0$ $\& \mathrm{cv}=29 \& \mathrm{xywh}=-3563 \% 252 \mathrm{C}-1244 \% 252 \mathrm{C} 15515 \% 252 \mathrm{C} 6998$

Søbye, E. \& Statistisk sentralbyrå. (2014). Folkemengdens bevegelse 1735-2014. En tabellstudie. Oslo: Oktober. 
Tjønneland, E. (1981). Vårt hjerte nær. I Trønder-Avisa 08.10.1981: 13. https://beta.nb.no/items/ 08 caa4018112a4e1265008886051d929;page $=12 \#$ ? $\mathrm{c}=0 \& \mathrm{~m}=0 \& \mathrm{~s}=0 \& \mathrm{cv}=12 \& \mathrm{xywh}=2639 \%$ $252 \mathrm{C} 4335 \% 252 \mathrm{C} 6114 \% 252 \mathrm{C} 2754$

Wåle, H. (1967). 26. november 1942. De norske jøders skjebnedag. Arbeiderbladet, 25. november 1967: 18-19.

Zborowski, M. og C. Freeze. (2007). Shtetl. I: Berenbaum, Michael \& Fred Skolnik (red.). Encyclopaedia Judaica (s.524-527). 2. utgave, vol. 18. Macmillan Reference USA. Gale Virtual Reference Library. Lest 8. desember 2017. http://go.galegroup.com/ps/i.do? $\mathrm{p}=\mathrm{GVRL} \& \mathrm{u}=\mathrm{oslo \& id}=\mathrm{GALE} \mid \mathrm{CX} 2587518416 \& \mathrm{v}=2.1 \& \mathrm{it}=\mathrm{r} \& \mathrm{sid}=$ exlibris\&authCount $=1$

\section{ARKIVER}

Jødisk museums arkiv (JMO). Dokument merket "Møtet 23/11.-87.”, i JMO.D00387. Dokumentsamling, Eva Scheer (ca. 1947-1992).

\section{Madelen Marie Brovold}

Universitetet i Oslo

Senter for Ibsen-studier

Postboks 1166

Blindern

0318 OSLO

Norway

madelen.brovold@ibsen.uio.no 